\title{
Investigation of the in vitro Anticancer Activity of Sorbus aria Extract on Prostate Cancer
}

\author{
${ }^{1}$ Tilbe ÖZAR, ${ }^{1} \mathrm{M}$. Fatih ÖZALP, ${ }^{* 1}$ Erdal EROĞLU \\ ${ }^{*}$ Manisa Celal Bayar Üniversitesi, Mühendislik Fakültesi, Biyomühendislik Bölümü, MANİSA, Türkiye
}

\begin{abstract}
Cancer is one of the common diseases observed in our country and worldwide with a high mortality rate. Although cancer has been treated with different applications such as chemotherapy, radiotherapy and surgical operation, the exact remedy of this disease has still not been found, yet. The fact that current treatment methods have severe side effects on patients has increased the interest in natural anticancer agents that are accepted easily and considered as safer by society. The aim of this study is to investigate the anticancer activity of whitebeam (Sorbus aria) that grows in the Central Anatolia Region in Turkey, extract on PC-3 human prostate cancer cells in vitro. The anticancer activity of the ethanol extract obtained from whitebeam fruits evaluated using MTT cell proliferation assay. Also, Folin-Ciocalteu assay and CUPRAC method were performed to determine total phenol content and antioxidant capacity of whitebeam fruits, respectively. Whitebeam fruit extract showed strong anticancer activity on prostate cancer in vitro. The obtained ethanol extract is found to be a promising natural anticancer agent in vitro, and our findings need to be verified with in vivo studies and clinical trials.
\end{abstract}

Key words: Prostate cancer, Sorbus aria, natural anticancer agents.

\section{Introduction}

Cancer, caused by uncontrolled proliferation and spread of abnormal cells, is the second most common cause of death worldwide. Generally, all healthy human cells grow and divide to multiply. During the cell cycle, if the cells are damaged or aged, they will go through apoptosis, and old cells are replaced with new ones. However this regular process is sometimes disrupted and abnormal cells, growing uncontrolled manner, form tumors. Some cancer cells can reach distant locations in the body through the lymph system and blood circulation. Thus, new tumors occur away from the original tumor site, which is called metastasis [1]. Prostate cancer, one of the most common type of cancer in men, is the second leading cause of deaths in men older than 65 years of age in western populations [2].

Although the exact solution of cancer is still not fully available, treatments such as surgical removal of the prostate gland, radiotherapy, chemotherapy, and hormone treatment are generally used to save lives [3]. However, those treatment methods possess serious side effects such as hair 
loss, nausea, fatigue, anemia, mucositis, infertility, and diarrhea [4]. Plant-based drug development studies have recently been gaining interest since natural agents are considered as safer with no or less side effects on normal cells.

S. aria, also known as whitebeam, is a deciduous, slow-growing, small to medium-sized shrub or tree (Figure 1). Leaves of whitebeam change color with the season. Light green leaves are seen in spring, dark green leaves are seen in summer, and yellow leaves are observed in fall. Whitebeam has a lifespan of approximately 100-200 years [5].

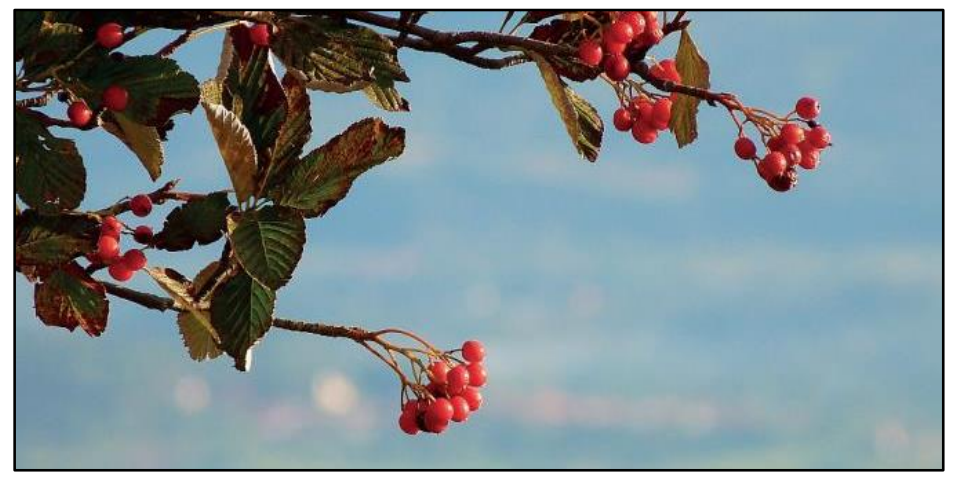

Figure 1. Leaves and fruits of S. aria [4].

In this study, the anticancer effects of whitebeam plant on prostate cancer were investigated. Also, total phenol content and antioxidant capacity of whitebeam were determined. Our findings showed that ethanol extract of whitebeam with a significant phenol content detected displayed a promising anticancer activity on prostate cancer in vitro and this plant needs to be further investigated with in vivo test and clinical studies.

\section{Materials and Method}

\subsection{Ethanol Extraction from fruits of whitebeam}

Fruits of whitebeam, obtained from a local bazaar at Isparta, Turkey, were washed with deionized water upon arrival in the laboratory. Then, 12 grams of fruits were mixed with $70 \mathrm{ml}$ ethanol and the mixture was sonicated for 5 minutes. After sonication, fruits were stirred for 30 minutes at magnetic stirrer. The supernatant was transferred in a clean bottle, and the pellet was mixed with $30 \mathrm{ml}$ of ethanol. This process repeated three times. In the last repeat, $20 \mathrm{ml}$ of ethanol was used. The collected supernatants were filtered with Whatman grade 41 filter paper. $44 \mathrm{ml}$ of deionized water were added into a filtered solution. The final solution was evaporated in a rotary evaporator at $40{ }^{\circ} \mathrm{C}$ and $200 \mathrm{rpm}$ for 1 hour until the removal of ethanol [6].

\subsection{Determination of total phenol content using Folin-Ciocalteu assay}

The amount of total phenol was determined using Folin-Ciocalteu assay. For the total phenolic 
capacity, a whitebeam stock solution $(1 \mathrm{mg} / \mathrm{ml})$ was prepared using dimethyl sulfoxide (DMSO). First, $20 \mu \mathrm{l}$ of whitebeam stock solution was pipetted into a well of the 96-well plate. Then, 100 $\mu \mathrm{l}$ of Folin-Ciocalteu phenol reagent was added into the whitebeam stock solution. The mixture of Folin-Ciocalteu phenol reagent and the stock solution was incubated at room temperature for 2.5 minutes in 96-well plates. After incubation, $80 \mu \mathrm{l}$ of sodium carbonate was added into each well. The final mixture was incubated in 96-well plates at room temperature for 1 hour at dark and then the absorbance of the wells was measured at $775 \mathrm{~nm}$ using a plate reader (Multiskan FC, Thermo Fisher Scientific, US).

\subsection{Determination of antioxidant activity using CUPRAC method}

Copper (II) chloride dihydrate solution (10 mM), Neocuproine hydrochloride monohydrate (Nc) solution $(7.5 \mathrm{mM})$, and ammonium acetate solution $(1 \mathrm{M})$ were utilized in the Cupric Reducing Antioxidant Capacity (CUPRAC) batch methodology. Copper solution and ammonium acetate solution $(\mathrm{pH}$ 7.0) were prepared in water. Neocuproine solution was prepared fresh in ethanol before each experiment. In a glass test tube, $1 \mathrm{ml}$ of Copper solution, $1 \mathrm{ml}$ of Neocuproine, and $1 \mathrm{ml}$ of ammonium acetate were mixed gently. Then, $1.1 \mathrm{ml}$ of $10 \mathrm{mg} / \mathrm{ml}$ whitebeam solution was also added into the same test tube. In a separate glass test tube, all reagents aforementioned were mixed except that DMSO was used in place of plant extract as control. After 30 minutes of incubation at dark, the absorbance of the solutions was measured at $450 \mathrm{~nm}$ using a spectrophotometer (Evolution 220, Thermo Fisher Scientific, US). Total antioxidant capacity was calculated using the following equation (1):

Total antioxidant capacity $(\mathrm{mM}$ Trolox / g sample $)=($ Absorbance / 16700 $) \times($ Total volume $(\mathrm{ml})$ / Sample volume $(\mathrm{ml})) \times($ Dilution factor $) \times($ Extraction volume $(\mathrm{ml}) /$ Sample weight $(\mathrm{g}))$

\subsection{MTT cell proliferation assay}

For the MTT assay, the stock solution of the extract $(10 \mathrm{mg} / \mathrm{ml})$ was prepared in DMSO. The stock solution was then diluted with Dulbecco's Modified Eagle Media supplemented with \%10 FBS and $\% 1$ antibiotic/antimycotic (DMEM-10) to sub-concentrations of $100 \mu \mathrm{g} / \mathrm{ml}, 50 \mu \mathrm{g} / \mathrm{ml}$, $25 \mu \mathrm{g} / \mathrm{ml}, 10 \mu \mathrm{g} / \mathrm{ml}$. PC-3 human prostate cancer cells $\left(1 \times 10^{4}\right.$ cell/well $)$ diluted in DMEM-10 were incubated in wells of 96 -well plates in an incubator at $37{ }^{\circ} \mathrm{C}$ and $5 \% \mathrm{CO}_{2}$ for 24 hours. After incubation, the previously diluted extract solutions were replaced with DMEM-10. Later, the plates were incubated in the $\mathrm{CO}_{2}$ incubator. On the day of the test, $10 \mu \mathrm{l}$ of MTT dye solution $(5 \mathrm{mg} / \mathrm{ml}$ in PBS) was added into each well and the plate was incubated in an incubator for an additional 2 hours. The test was repeated for 24, 48, and 72 hours and the absorbance of plates was measured at 570 and $690 \mathrm{~nm}$ wavelengths. In cell viability calculations, the values obtained by subtracting the absorbance value measured at $690 \mathrm{~nm}$ from the absorbance value measured at $570 \mathrm{~nm}$ were used. Cell viability (\%) was calculated using the following equation (2):

$\%$ Cell viability $=($ Sample absorbance $/$ Control absorbance $) \times 100$ 


\section{Results}

\subsection{Total phenol content of whitebeam fruits extract}

Folin-Ciocalteu assay is widely used to measure the total phenolic contents of plant extracts. The total phenol content measured as gallic acid equivalent (GAE). The total phenol content of whitebeam fruits extract was determined $30.47 \mathrm{mg}$ gallic acid equivalent phenolic compound per g sample.

\subsection{Antioxidant capacity of whitebeam fruits extract}

To determine the amount of antioxidant in a biological sample, Total Antioxidant Capacity (TAC) assay is one of the most common tests. TAC is given as Trolox Equivalent Antioxidant Capacity (TEAC). CUPRAC assay results showed that ethanol extract of whitebeam fruits has $469.77 \mu \mathrm{mol}$ Trolox per g sample.

\subsection{Anticancer activity of whitebeam fruits extract}

The graph showing the anticancer activity of whitebeam fruits extract for 24-48-72 hours was presented in Figure 2. Overall, the cell viability was reduced upon treatment with whitebeam fruits extract in a dose-dependent manner. At high concentrations, $100 \mu \mathrm{g} / \mathrm{ml}$, and $50 \mu \mathrm{g} / \mathrm{ml}$, cell viability was determined below $\% 10$. For $25 \mu \mathrm{g} / \mathrm{ml}$ and $10 \mu \mathrm{g} / \mathrm{ml}$ concentrations of the extract, the highest inhibition was achieved at 24 hours incubation.

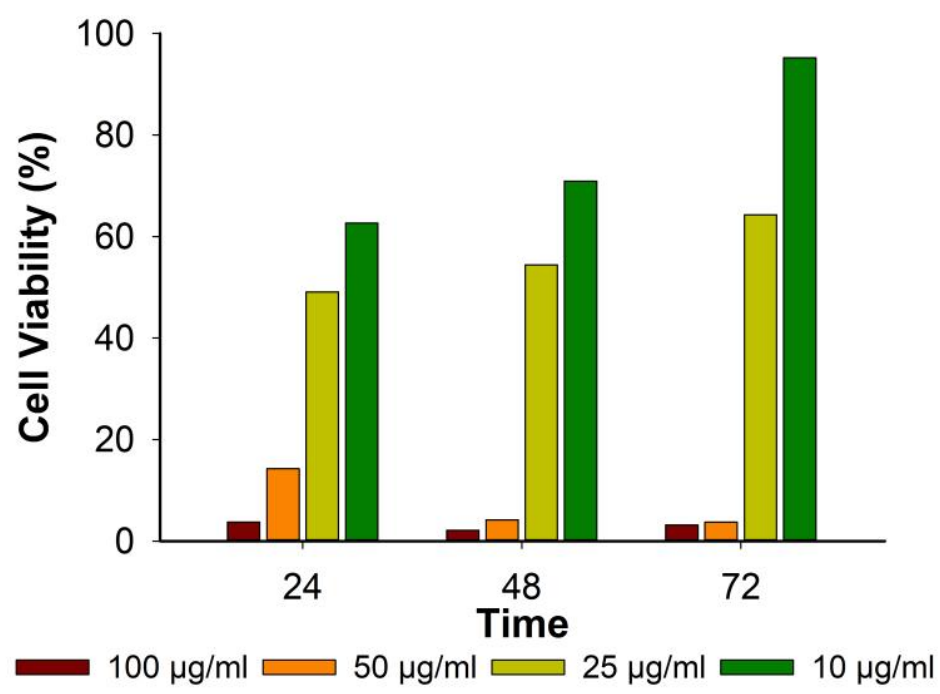

Figure 2. MTT cell viability test results.

Control group, $1 \%$ DMSO, showed $86.3 \%$ cell viability at 24 hours, $77.76 \%$ cell viability at 48 hours, and $\% 99.99$ cell viability at 72 hours. The average $\mathrm{IC}_{50}$ value for 24 th hours was 
calculated as $25.4 \mu \mathrm{g} / \mathrm{ml}$ for the agent. It was clearly observed that the ethanol extract of whitebeam fruits has a significant anticancer effect against prostate cancer cell line PC-3 in vitro.

\section{Discussion}

According to the literature, the phenolic amount of whitebeam fruits was found significantly low compared to other well-known plants analyzed. On the other hand, its antioxidant capacity was determined better than the phenolic amount (Table 1). TEAC values showed that the extract of whitebeam fruits presents a significant antioxidant capacity compared to some plants which are commonly consumed as food such as mustard and white mulberry. However, some growing conditions such as soil type, nutrient amount of soil, rainfall, etc are known to affect the phenolic amount and antioxidant capacity of plant extracts. [7]

Table 1. Comparisons of GAE and TEAC values for $S$. aria with other plants' extracts.

\begin{tabular}{|c|c|c|c|c|c|}
\hline Plant & Common Name & Part of Plant & GAE $(\mathbf{m g} / \mathbf{g})$ & TEAC $(\boldsymbol{\mu m o l} / \mathbf{g})$ & References \\
\hline Sorbus aria & Whitebeam & Fruit & 30.47 & 469.77 & This study \\
\hline Cnicus benedictus & Cnicus & Root & 1.57 & 17.61 & {$[8]$} \\
\hline Ocimum basilicum L. & Basil & Stem & 28.90 & 266.42 & {$[8]$} \\
\hline Morus alba L. & White mulberry & Fruit & 19.02 & 233.91 & {$[9]$} \\
\hline Salvia officinalis & Sage & Leaf & 26.89 & 231.60 & {$[10]$} \\
\hline Brassica hirta & Mustard & Seed & 20.40 & 45.90 & {$[10]$} \\
\hline Matricaria chamomilla & Chamomile & Flower & 16.77 & 153.94 & {$[10]$} \\
\hline Lonicera japonica & $\begin{array}{c}\text { Japanese } \\
\text { honeysuckle }\end{array}$ & Flower & 27.36 & 121.97 & {$[11]$} \\
\hline Murraya koenigii & Curry & Leaf & 1.18 & 1.13 & {$[12]$} \\
\hline
\end{tabular}

According to the MTT cell proliferation test results, the fruits of whitebeam showed significant anticancer activity on prostate cancer, and the highest anticancer activity was reached at the 24th hour. When the concentration groups were compared, higher anti-cancer activity was determined at the concentration of $50 \mu \mathrm{g} / \mathrm{ml}$ and above. As a result, it has been observed that whitebeam is a highly effective anticancer agent on PC-3 cancer cells in vitro. In addition, IC 50 value was calculated as $25.4 \mu \mathrm{g} / \mathrm{ml}$ and it is shown in Table 2 by comparing it with other similar studies in the literature. The $\mathrm{IC}_{50}$ value obtained in this study is one of the lowest values when compared with similar studies in the literature. 
Table 2. $\mathrm{IC}_{50}$ values of various plant extracts on cancer cells.

\begin{tabular}{|c|c|c|c|c|c|}
\hline Plant & Common Name & Part of Plant & Cell Line & IC $5 \mathbf{5 0}(\boldsymbol{\mu g} / \mathbf{m l})_{\text {References }}$ \\
\hline Sorbus aria & Whitebeam & Fruit & PC-3 & 25.4 & This study \\
\hline Moringa peregrina & Miracle tree & Seed & PC-3 & 600.42 & {$[13]$} \\
\hline Diospyros kaki & Persimmon & Leaf & PC-3 & 57.7 & {$[14]$} \\
\hline Azadirachta indica & Nimtree & Leaf & PC-3 & 100 & {$[15]$} \\
\hline Carica papaya & Papaya & Leaf & PC-3 & 950 & {$[16]$} \\
\hline Daniellia oliveri & $\begin{array}{c}\text { African Copaiba } \\
\text { Balsam Tree }\end{array}$ & Leaf & PC-3 & 130 & {$[17]$} \\
\hline Vitex doniana & Black plum & Root & PC-3 & 177.3 & {$[17]$} \\
\hline Cajanus cajan & Pigeonpea & Leaf & MCF-7 & 52 & {$[18]$} \\
\hline Lophira alata & Azobé & Tree bark & HepG2 & 32.98 & {$[19]$} \\
\hline Fagara xanthoxyloides & Artar root & Root & CWR-22 & 44 & {$[20]$} \\
\hline Morinda lucida & Brimstone tree & Root & HL-60 & 171 & {$[21]$} \\
\hline
\end{tabular}

\section{Conclusions}

Anticancer activity was investigated by performing the ethanol extraction method for whitebeam fruits. MTT cell proliferation test was applied to evaluate its anticancer effect on prostate cancer. From the MTT cell viability test, the $\mathrm{IC}_{50}$ value was calculated as $25.4 \mu \mathrm{g} / \mathrm{ml}$ for the extract of whitebeam fruit, which is one of the lowest values in the literature. In this study, other biological activities of whitebeam, such as total phenol and antioxidant content, were also investigated. Folin-Ciocalteu method was used for total phenol analysis and the CUPRAC method was used for antioxidant analysis. Significant antioxidant activity was also determined from the extract. In conclusion, the ethanol extract of whitebeam fruits was found as a promising antioxidant and anticancer agent. The in vitro findings of this work should be expanded to in vivo test and clinical trials to develop an anticancer drug.

\section{Acknowledgements}

The authors would like to thank Asst. Prof. Dr. Mehmet Emin USLU and M.Sc. student Ezgi R. TAYMAZ for their help in plant extraction, lyophilization, and Folin-Ciocalteu assay. We would like to extend our appreciation to Şeyda Nur GIRGIN for all her supports in the experiments. 


\section{References}

[1] What Is Cancer?. National Cancer Institue. Avaible: https://www.cancer.gov/aboutcancer/understanding/what-is-cancer. Last Accessed: 25-Jun-2020.

[2] Kumar S, Eroglu E, Stokes JA 3rd, Scissum-Gunn K., Saldanha SN, Singh UP et al. Resveratrol induces mitochondria-mediated, caspase-independent apoptosis in murine prostate cancer cells. Oncotarget 2017;8(13):20895-908.

[3] Ochwang'i DO, Kimwele CN, Oduma JA, Gathumbi PK, Kiama SG, Efferth T. Cytotoxic activity of medicinal plants of the Kakamega County (Kenya) against drug-sensitive and multidrug-resistant cancer cells. J Ethnopharmacol 2018;215:233-40.

[4] Chemotherapy. Hational Health Service. Avaible: https://www.nhs.uk/conditions/chemotherapy/ Last Accessed: 25-Jun-2020.

[5] Welk E, de Rigo D, Caudullo G. Sorbus aria in Europe: distribution, habitat, usage and threats. In: San-Miguel-Ayanz J, de Rigo D, Caudullo G, Houston Durrant T, Mauri A, editors. European Atlas of Forest Tree Species, Luxembourg: Publications Office of the EU; 2016, p. 174-75.

[6] Eroğlu E. Efficacy of natural antimicrobials on food-borne pathogens and their applications. İzmir Institute of Technology 2008; Master of Science Thesis.

[7] Kouki M, Manetas Y. Resource availability affects differentially the levels of gallotannins and condensed tannins in Ceratonia siliqua. Biochem Syst Ecol 2002;30:631-9.

[8] Kirca A, Arslan E. Antioxidant capacity and total phenolic content of selected plants from Turkey. Int J Food Sci Technol 2008;43:2038-46.

[9] Li S, Li S, Gan R, Song F, Kuang L, Li H. Antioxidant capacities and total phenolic contents of infusions from 223 medicinal plants. Ind Crops Prod 2013;51:289-98.

[10] Fernandes RPP, Trindade MA, Tonin FG, Lima CG, Pugine SMP, Munekata PES, et al. Evaluation of antioxidant capacity of 13 plant extracts by three different methods: cluster analyses applied for selection of the natural extracts with higher antioxidant capacity to replace synthetic antioxidant in lamb burgers. J Food Sci Technol 2016;53:451-60.

[11] Li H, Wong C, Cheng K, Chen F. Antioxidant properties in vitro and total phenolic contents in methanol extracts from medicinal plants. LWT - Food Sci Technol 2008;41:385-90.

[12] Tukun AB, Shaheen N, Banu CP, Mohiduzzaman M, Islam S, Begum M. Antioxidant capacity and total phenolic contents in hydrophilic extracts of selected Bangladeshi medicinal plants. Asian Pac J Trop Med 2014;7:S568-73.

[13] Abou-Hashem MMM, Abo-elmatty DM, Mesbah NM, Abd EL-Mawgoud AM. Induction of sub-G0 arrest and apoptosis by seed extract of Moringa peregrina (Forssk.) Fiori in cervical and prostate cancer cell lines. J Integr Med 2019;17:410-22.

[14] Ding Y, Ren K, Dong H, Song F, Chen J, Guo Y, et al. Flavonoids from persimmon (Diospyros kaki L.) leaves inhibit proliferation and induce apoptosis in PC-3 cells by activation of oxidative stress and mitochondrial apoptosis. Chem Biol Interact 2017;275:210-7.

[15] Gunadharini DN, Elumalai P, Arunkumar R, Senthilkumar K, Arunakaran J. Induction of apoptosis and inhibition of PI3K/Akt pathway in PC-3 and LNCaP prostate cancer cells by ethanolic neem leaf extract. J Ethnopharmacol 2011;134:644-50. 
[16] Pandey S, Walpole C, Cabot PJ, Shaw PN, Batra J, Hewavitharana AK. Selective antiproliferative activities of Carica papaya leaf juice extracts against prostate cancer. Biomed Pharmacother 2017;89:515-23.

[17] Fadeyi SA, Fadeyi OO, Adejumo AA, Okoro C, Myles EL. In vitro anticancer screening of 24 locally used Nigerian medicinal plants. BMC Complement Altern Med 2013;13:79.

[18] Schuster R, Holzer W, Doerfler H, Weckwerth W, Viernstein H, Okonogi S, et al. Cajanus cajan -a source of PPAR $\gamma$ activators leading to anti-inflammatory and cytotoxic effects. Food Funct 2016;7:3798-806.

[19] Kuete V, Fokou FW, Karaosmanoğlu O, Beng VP, Sivas H. Cytotoxicity of the methanol extracts of Elephantopus mollis, Kalanchoe crenata and 4 other Cameroonian medicinal plants towards human carcinoma cells. BMC Complement Altern Med 2017;17:280.

[20] Kassim OO, Copeland RL, Kenguele HM, Nekhai S, Ako-Nai KA, Kanaan YM. Antiproliferative activities of Fagara xanthoxyloides and Pseudocedrela kotschyi against prostate cancer cell lines. Anticancer Res 2015;35:1453-8.

[21] Appiah-Opong R, Tuffour I, Annor GK, Blankson-Darku AD, Cramer P, Kissi-Twum AA, et al. Antiproliferative, antioxidant activities and apoptosis induction by Morinda lucida and Taraxacum officinale in human HL-60 leukemia cells. J Glob Biosci 2016;5:4281-91. 